\title{
Franceses contra portugueses? Conjuração Baiana e nacionalidades impossíveis
}

\author{
The French against the Portuguese? Conjuração Baiana and impossible nationalities
}

Franceses contra portugueses? Conjuração Baiana y nacionalidades imposibles

Rodrigo Oliveira Fonseca

\section{Resumo}

Neste artigo discutimos o deslocamento político e discursivo que, em meio à Conjuração Baiana de 1798, faz com que "nação" deixe de se referir à sujeição a uma determinada soberania e passe a significar outra coisa que não uma "troca de senhores", apontando assim para a construção de um projeto político que não cabe no campo ideológico dominante, aquele que impõe uma visibilidade, uma alternância e uma organização das contradições a seu próprio modo. Se não se tratava de antagonismo entre "ser português" e "ser francês" na Bahia ao final do século XVIII, se o verdadeiro antagonismo se dava entre república e monarquia, é o caso de sublinhar tanto a dificuldade de assimilação do povo mecânico e não branco à sociedade política local, como o desentendimento e a equivocidade desse "ser francês" no interior da formação escravista colonial. Consi- deramos, enfim, que aquilo que os sujeitos dizem pode importar tanto quanto aquilo que deles se diz: os revolucionários baianos não tiveram de pagar apenas pela sua origem social, mas também e fundamentalmente pelo que disseram e fizeram ouvir.

Palavras-chave: Conjuração Baiana. Desentendimento. Discurso. Ideologia. Nação.
Mestre em História pela PUC-Rio e Doutor em
Letras pela UFRGS, tendo defendido a tese in-
titulada "A interdição discursiva: o caso da Con-
juração Baiana de 1798 e outros limites à parti-
cipação popular na história política brasileira".

Recebido em: 24/10/2012 Aprovado em: 15/02/2013 http://dx.doi.org/10.5335/hdtv.13n.1.3002 
[...] com frequência, o chamado "partido do estrangeiro" não é propriamente aquele que é habitualmente apontado como tal, mas precisamente o partido mais nacionalista, que, na realidade, mais do que representar as forças vitais do próprio país, representa sua subordinação e servidão econômica às nações ou a um grupo de nações hegemônicas. ${ }^{1}$

Antonio Gramsci, Cadernos do Cárcere

Salvador, agosto de 1798, dias de "conjuração", os planos de um levante republicano percorrem as ruas da cidade a boca miúda. Em meio ao trabalho de abordagem dos revolucionários dos setores populares, temos notícia de um escrav(izad)o que, ao ser convidado para se juntar ao "partido da liberdade", teria respondido que não o faria pois "não era francês e sim português" . ${ }^{2}$ Tal resposta também teria sido dada por um procurador de causas diante do prenúncio de que, em breve, tudo ali se tornaria francês:

[...] O dito João de Deos trazia calçados uns chinelins com bico muito comprido, e a entrada muito baixa, e calçoens tão apertados, que vinha muito descomposto, lhe extranhou elle testemunha, ao que respondeo, = cale a boca, este trajar he Francez, muito breve verá Vossa mercê tudo francez; $[\ldots]=$ o que ouvindo elle testemunha lhe respondeo, $=$ Eu sou Portugues, e jamais serei Francez, vá-se com os diabos = e dito isto se retirou, e o dito João de Deos ficou rindo-se. E passados poucos dias se fes publico, e notoriamente sabido, que em alguns Lugares públicos, e nas Igrejas desta Cidade apparecerão papeis sediciosos... ${ }^{3}$

O primeiro caso relatado, de fato, nos impressiona mais, pela condição de cativo do que se afirma português. Esse para nós é um caso que, se não pode ser extrapolado, projetando uma hegemonia sem fissuras de um projeto identitário português (qual seria este?) em suas possessões - e uma hegemonia que se estenderia até mesmo junto àqueles a quem não estava dirigida, como veremos -, serve para mostrar de modo exemplar a existência de um campo superestrutural em que as nacionalidades se afirmam com base em projetos políticos antagônicos e na lealdade e falta de lealdade à Coroa Portuguesa. Logo, mostra a existência de um verdadeiro campo minado, no momento histórico em que a conjuntura revolucionária francesa transborda o Atlântico e tempera as velhas tensões e traumas da formação social escravista, à flor da pele diante do quadro de intensa prosperidade da economia açucareira, motivada pela crise da produção antilhana, o desabastecimento de víveres que também se dava como consequência direta daquela prosperidade da exportação açucareira, com a redução das áreas de plantio de mandioca, e, em especial, a agitação política nas grandes cidades coloniais.

Partilhamos da convicção de István Jancsó e João Paulo Pimenta de que "todo projeto de uma nova ordem implica o esboço mais ou menos preciso da comunidade que partilhará, e de como deverá fazê-lo", e nosso propósito aqui é o de compreender de que modo tal esboço, no caso da Conjuração de 1798, se ancora numa identificação equívoca com "os franceses" que pode ter custado mais aos revolucionários do que a sua própria origem social. 
Reivindicações da identidade portuguesa

\section{na América (as artes de lembrar)}

Todo o processo de conquista portuguesa na América e sua manutenção foi atravessado por frequentes sublevações dos povos, tanto por parte dos colonizados, reduzidos à dominação e ao trabalho compulsório, quanto por parte dos colonos, peças estratégicas para que das "conquistas ultramarinas" (portuguesas) se pudesse efetivar "exploração colonial" (escravista). No que tange à "colonização dos colonos", 6 especialmente após a libertação do domínio Habsburgo em 1640 e a luta contra os holandeses no nordeste brasileiro até 1654 , a Coroa portuguesa teve de lidar com o pactismo, cultura política da Segunda Escolástica, força ideológica atuante nas revoltas coloniais. Remetendo a um imaginário pacto original a ser lembrado, os colonos, na condição de vassalos, reclamavam da usurpação dos direitos naturais da comunidade portuguesa nas mãos de "ministros ruins", agentes públicos que agiriam em benefício próprio e menosprezariam "o sangue, as vidas e as fazendas" dos primeiros súditos que na colônia asseguraram a conquista, aumentando ainda mais o "estado de miséria" em que os descendentes daqueles se encontravam. ${ }^{7}$

Os súditos portugueses desse outro lado do Atlântico buscavam meios para incidir sobre a escolha e o envio de ministros e o seu comportamento no cargo, de modo a que "tudo não seja tirania, interesses e aumento da fazenda própria, em grande prejuízo dos vassalos de Vossa Majestade" (carta do provedor-mor da fazenda do Estado do Brasil, de 1661). ${ }^{8}$ Também em relação aos tributos os homens de negócio como os da Bahia queriam ter voz ativa e poder julgar a sua legitimidade, afirmando em 1728 que deveriam para isso ser "convocados e ouvidos os povos". ${ }^{9}$ Os colonos, autorreferidos enquanto súditos e vassalos, prometiam lealdade ao rei, mas para isso "Sua Majestade [...] os devia amparar e não destruir", esperando dos "senhores reis de Portugal [...] tratarem os seus vassalos como pais e não como senhores". ${ }^{10}$ À rotineira alegação de miséria, somava-se a retórica de comparação com a condição dos seus cativos, comum tanto na América portuguesa quanto na inglesa - os produtores de tabaco da Virgínia, por exemplo, diante das restrições mercantilistas, sentiam-se, nas palavras de George Washington, "tão miseravelmente oprimidos quanto nossos próprios negros" ${ }^{11}$

Quanto aos escravizados, estes eram certamente vistos como homens, tanto que a sociedade escravista reconhecia a sua responsabilidade penal, ${ }^{12}$ mas não lhes foi reconhecido nenhum pertencimento à comunidade portuguesa (até o período pombalino, com o fim da escravidão no Reino). Nem mesmo o preceito filipino da "liberdade natural", estendido aos indígenas, fora reconhecido nos africanos. ${ }^{13}$ Como escreve Ubiratan Castro de Araújo, referindo-se a Salvador, para a grande maioria da população urbana composta pelos descendentes de africanos "a cidade é uma prisão", na qual as piores celas estão reservadas aos africanos, vistos como "os mais ferozes dos bárbaros, como os mais escravos entre os escravos"14 estigma este que serviu à legitimação ideológica do trato negreiro, pois este supostamente não destruía nenhuma legítima família, 
subtraía aqueles povos do paganismo e misericordiosamente salvava aqueles nativos deles próprios, de sua alegada barbárie. ${ }^{15}$

$\mathrm{O}$ acirramento e a brutalidade do combate aos indígenas (por longo tempo feitos cativos pelos paulistas e nas capitanias do Norte) e aos quilombolas (em praticamente todas as regiões) acabavam favorecendo a mestiçagem e a busca de integração à sociedade escravista por parte da maioria urbana descendente de africanos e nascidos no Brasil, parte fundamental do povo mecânico, a classe trabalhadora urbana da época. Mas a despeito de tal busca de integração, era com grande desconfiança que as autoridades metropolitanas enxergavam não somente aos forros - pretos (africanos) e crioulos (nascidos no Brasil) - e aos pardos livres (de ascendência africana). $O$ conjunto da população colonial era comumente tida por atrevida e insubordinada pelos agentes reinóis. Domingos Álvares Teles Brandão, funcionário régio em Minas Gerais, escreve ao Reino em 1736 queixando-se de que "canalha semelhante não há no mundo, sendo a maior galhardia dos donos das fazendas proteger ladrões e matadores que utilizão em seu serviço, quizas porque elles forão e são da mesma molde". ${ }^{16}$ Visando desfazer essa imagem constantemente lembrada no Reino sobre o caráter dos habitantes da colônia, um conselheiro de D. João VI, D. Luís da Cunha, afirmava no início do século XVIII que "as cidades do Brasil não são povoadas desta mizeravel gente, mas de muitos e bons portugueses que dela se servem, como em Lisboa nos servimos de negros". ${ }^{17}$

O fato de ter o Brasil "no sangue" era um fator a ser lembrado por pelo menos três gerações, dado que nos termos jurídicos da época, a figura do brasileiro era a de todo aquele filho e neto de alguém nascido nas possessões portuguesas da América - mesmo se este em questão tivesse nascido no Reino. $^{18}$

Vemos assim que a "colonização dos colonos" e a sua vassalagem e pertença à comunidade portuguesa passavam por caminhos nos quais, seguindo a lógica de poder colonial metropolitano, tratava-se sempre de "tentar assegurar" o lugar proeminente do colonizador. É mesmo importante que esteja frisado esse "tentar assegurar", já que devemos considerar que esse agente de conquista imperial que se acopla à própria conquista e se transforma em agente de "reiteração ampliada de uma formação societária particular informadora dos objetivos de sua ação", na expressão de Jancsó e Pimenta, ${ }^{19}$ é integrante de uma formação social própria, engendrada pela colonização portuguesa, mas que não pode ser compreendida apenas por esta. ${ }^{20}$

A reivindicação da identidade portuguesa por parte de colonos e colonizados tinha assim relação com essas questões-limite, que ajudam a entender a acusação em 1822 por parte dos deputados eleitos no Brasil para as Cortes Gerais e Extraordinárias e Constituintes da Nação Portuguesa de que foram os deputados eleitos em Portugal os que romperam a unidade da nação. ${ }^{21}$

\section{Pressões da política identitária portuguesa (as artes de fazer esquecer)}

Por meio daquela concepção pactista e corporativa de que falamos acima, aos deveres de lealdade dos súditos, corresponde- 
riam os deveres de amparo e proteção do rei para com eles, numa equação sempre tensa a qual o reformismo ilustrado português não pretendia dar conta. A singularidade do reformismo ilustrado português, com sua agenda modernizadora, que chegou a cogitar o fim da escravidão nas colônias (o que provavelmente teria gerado uma separação política antecipada), passava também pela neutralização e enfrentamento a tais teorias corporativas, entraves à centralização absolutista na medida em que alguns de seus teóricos defendiam até mesmo o regicídio para que a comunidade "retomasse" o seu poder em caso de tirania. ${ }^{22}$

Nesse sentido, às artes de lembrar uma pertença podemos acrescentar outras artes, atuantes em prol de esquecimentos que, além de apagarem ou neutralizarem trajetórias coletivas ancestrais que poderiam enobrecer e legitimar a posição dos colonos no seio da nação portuguesa, visavam apagar também a presença dos colonizados, essa "miserável gente" que formava a ampla maioria do continente brasileiro.

Afilhado do Marquês de Pombal, ministro da Marinha e do Ultramar português entre 1796 e 1801, um dos primeiros leitores de Adam Smith em Portugal e influente sobre os círculos ilustrados na América portuguesa, D. Rodrigo de Souza Coutinho alimentava o sonho de um império luso-brasileiro, um grande Estado atlântico federativo. Contudo, nesse seu projeto não haveria ruptura com o mercantilismo, com a divisão internacional do trabalho nos dois lados do oceano, nem com a centralidade política do lado europeu, idealizando apenas um quadro político-identitário futuro no qual "o português nascido nas quatro partes do mundo se julgasse somente português e não se lembr[ass]e senão da glória e da grandeza da Monarquia". ${ }^{23}$

Esse "não lembrar" não é gratuito ou inocente e esteve presente no interior de iniciativas tomadas desde o interior das regiões coloniais que visavam também às artes de lembrar do tópico anterior. Em Salvador, por exemplo, no ano de 1724, é fundada a "Academia Brasílica dos Esquecidos" pelo vice-Rei da época, Vasco Fernandes de Meneses, em meio à onda do movimento academicista português, que, do lado de cá, cumpriria o papel de erigir a construção imaginária de um Brasil que ignora os sentidos de brasilidade que vinham se configurando na colonização. ${ }^{24} \mathrm{~A}$ História da América Portuguesa, de Sebastião da Rocha Pita, editada em 1730 (mas escrita em 1724), é resultado das discussões e propósitos da Academia Brasílica dos Esquecidos, que não durou mais que um ano.

Tal Brasil imaginário pode bem ser percebido na língua através da reiteração de formas superlativizadas e saturadas quanto à fertilidade do Brasil - "a [terra] mais bela", "os maiores rios" -, com a extensão de suas propriedades aos que aí nascem - "terra onde florescem talentos", "é fama acreditada entre os seus naturais que esta água faz vozes suaves nos músicos e mimosos carões nas damas", "a Nossa Portuguesa América (e principalmente a província da Bahia), que na produção de engenhosos filhos pode competir com Itália e Grécia" - e o apagamento (via indeterminação do sujeito gramatical) dos produtores de denominações das coisas próprias do Brasil - "[isso] a que 
chamam remel", "chamados manaíbas", "que nomeiam tapitis", "que chamam bolandeira", "a que chamam potiassus". ${ }^{25}$ Já na própria denominação do nativo originário americano enquanto "índio", natural das Índias, tem-se um total impedimento à autonomeação, ao falar-se. ${ }^{26}$

O que deve ser apagado, esquecido, em nome de um projeto de construção de um Brasil imaginário, perfeitamente integrado ao Reino, somente português - na mesma direção que acima vimos sair da pena daquele conselheiro de D. João VI - são dizeres como estes que sublinham como "males" do continente os seus habitantes: "terras de criação de todas as coisas deste mundo não há em toda a terra como esta, mas o gentio dela é o demônio" (dito por um mestre de obras na Bahia em 1551). ${ }^{27}$ Esse lugar de repulsa pela realidade brasileira, em séculos de desenvolvimento escravista colonial, é reconfigurado, de modo que o demônio progressivamente vai passando para o corpo da "plebe", "descrição pejorativa do 'povo' insubordinado petulante e formado por negros, mulatos e mestiços". ${ }^{28}$

Em 1759 a "Academia Brasílica dos Acadêmicos Renascidos" visa dar continuidade ao trabalho dos acadêmicos esquecidos, escrevendo nova história da América Portuguesa ("história eclesiástica, universal e secular") sob o impulso da chegada ao Brasil do conselheiro do ultramar José Mascarenhas de Melo. Pelos seus estatutos,

os fiéis vassalos d'El Rei nosso senhor, que habitam nesta capital dos seus estados do Brasil [...] hão de escrever tão admiráveis progressos, a honra da Pátria, e a glória dos doutos portugueses americanos. ${ }^{29}$
Bethania Mariani avalia que neste empreendimento, instituidor de um "simulacro de Portugal", é ainda mais radical o silenciamento do Brasil, mero lugar e continente, o objeto de uma história na qual mesmo os portugueses nascidos na colônia não são sujeitos. Dado o caráter xenofágico da economia brasileira, o seu intenso consumo de estrangeiros, e a decuplicação da população brasileira no século XVIII, amplia-se certamente o alcance de políticas de esquecimento como essa.

Fator essencial de esquecimento da heterogênea realidade brasileira é a imposição pombalina da língua portuguesa (ou de uma língua portuguesa, que não era exatamente a mesma das regiões subalternas no Reino, como a Estremadura e o Alentejo) sobre as outras línguas faladas Brasil, algumas delas já gramatizadas, como a língua geral, o cariri e o quimbundo. ${ }^{30} \mathrm{O}$ texto que institui o Diretório dos Índios, em 1755, explicita a consciência que então se tem do papel da língua no processo de sujeição:

Sempre foi máxima inalteradamente praticada em todas as nações que conquistaram novos Domínios introduzir logo nos Povos conquistados seu próprio idioma, [...] um dos meios mais eficazes para desterrar dos Povos rústicos a barbaridade de seus antigos costumes; e ter mostrado a experiência que ao mesmo passo que se introduz neles o uso da Língua do príncipe que os conquistou, se lhes radica também o afeto, a veneração, e a obediência ao mesmo Príncipe. $^{31}$

Cabe acrescentar que, se a língua era vista enquanto arma potencial para calar e dobrar povos, já não era tida como o elemento central da instituição de uma nação, ideia 
vigente no século XVII, mas que no XVIII parece ter sido substituída pela centralidade própria do Estado/Monarquia. ${ }^{32}$ Segundo o dicionário de Raphael Bluteau, de 1728, o verbete "nação" designa "a gente que vive em alguma grande região, ou Reino, debaixo do mesmo Senhorio. Nisso se diferencia nação de povo, porque nação compreende muitos povos". ${ }^{33}$ Este é mesmo o sentido das duas respostas que vimos no início do artigo quanto ao "ser português" em contraposição ao "ser francês" dos revolucionários baianos. Indo ao dicionário de Luiz Maria da Silva Pinto, de 1832, o verbete adquire outra referência, certamente tributária da era das revoluções do século XVIII: "[...] a gente de um paiz, que se governa por suas leis particulares". ${ }^{34}$ Impossível não destacar a equivocidade desse "que se governa"...

Na lógica colonizadora, a falta de lealdade com o Estado monárquico português era percebida como caminho para outra, como aparece no dizer de um dos oficiais encarregados da repressão a uma revolta no sertão das Minas Gerais, em 1736, "esta gente não são vassalos del rei de Portugal, mas Turcos", ${ }^{35}$ reproduzindo de modo enviesado o dizer ibérico arcaico "tem mouro na costa" ou "anda mouro na costa", que alertava para a proximidade e a ameaça de embarcações magrebinas. Vale também considerar a reação enfurecida de um antigo oficial do exército prussiano que se rebela contra o internacionalismo da sociedade secreta maçônica da qual fizera parte, os Iluminados: “[...] sentimento cosmopolita, que é isso? És cidadão ou rebelde. Não há terceira alternativa". ${ }^{36}$

E quando não se tratam de "turcos" nem de "mouros" nos séculos XV a XVII, mas exatamente de "franceses" em fins do XVIII? E quando não se tratam de cidadãos ou rebeldes, mas de cidadãos rebeldes (de uma cidadania outra que pressupõe um gesto rebelde instituidor)?

\section{A equivocidade da identificação com os franceses no movimento de 1798}

Neste trabalho não nos interessa a presença francesa no movimento sedicioso baiano, com as expectativas de que fosse enviado apoio militar da França para o levante, presença e expectativas investigadas por Katia Mattoso, Luís Henrique Dias Tavares, István Jancsó e Marco Morel. ${ }^{37}$ Queremos compreender de que modo uma identificação imaginária com os franceses atuou política e discursivamente na reconfiguração de um "campo de experiências e horizonte de expectativas" dos sujeitos históricos da Conjuração Baiana - utilizando aqui os conceitos desenvolvidos por Reinhart Koselleck ${ }^{38}$ para problematizar as formas como o passado e o futuro são mobilizados em um determinado tempo presente, sendo que, no nosso caso, os pensamos ao lado das práticas agenciadoras de desejos e interesses que conformam a práxis dos sujeitos históricos, e, mais especificamente, seus "modos de subjetivação", entendidos enquanto

[...] produção, por uma série de atos, de uma instância e de uma capacidade de enunciação que não eram identificáveis num campo de experiência dado, cuja identificação caminha a par com uma reconfiguração do campo de experiência. ${ }^{39}$

Aqui entra em questão o trabalho sempre incompleto dos sujeitos históricos de 
construção dos seus "palanques", ${ }^{40}$ de onde podem "finalmente" falar, subtraindo-se de um lugar destituído de voz e vez, fazendo-se visíveis e audíveis. Esses "palanques" são ao mesmo tempo a instância e a capacidade dinâmica que condicionam as práticas discursivas dos sujeitos históricos, em meio às relações de força e às formas de combate nas quais os discursos ecoam ou não. Não se trata do descortinamento ou reconhecimento de um lugar prévio, uma readequação do corpo, da fala e dos dizeres frente a esse lugar (administrado pelos poderes dominantes ou mesmo pelas hipóteses socio-históricas do pesquisador). Trata-se mesmo do oposto a quaisquer mecanismos de adequação, apontando para formas de reação a um dano ou a um efeito indesejado causado pela incidência paradigmática e assediante de uma voz ordenadora, o que poderá sempre instaurar litígios e desentendimentos, valendo-se de modo especial da equivocidade dos dizeres, suas ambivalências e pontos de deriva. Mediante essa nova instância enunciativa uma comunidade política se realiza enquanto a subtração de uma ordem, um deslocamento histórico, onde deve ser sublinhado o papel da práxis, que pode ser pesquisado e mapeado pela configuração de uma rede de dizeres da formação social que desenha um "sujeito em processo nos textos", ${ }^{41}$ de modo a se poder considerar dialeticamente as contradições da história e as equivocidades da linguagem, e de modo também a instaurar um pensamento não do que é, mas do que surge. ${ }^{42}$

Façamos uma narrativa para esboçar, e não mais que isso, tais considerações teóricas junto a determinados fatos. Em uma das muitas de suas abordagens para conseguir gente disposta a lutar para viver "em igualdade e abundância", João de Deus, alfaiate pardo, um dos acusados de ser "cabeça" do movimento, teria dito a Joaquim José da Veiga (um dos denunciantes dos planos de levante), que ele

[...] tinha cara de Francez $=$ ao que respondeo elle denunciante, que tal não suppozesse ; porem continuou o dito João de Deos $=$ Que se calasse, que elle denunciante era esperto, e agil para hum negocio, e acção, que com elle queria tratar, pois convinha, que todos se fizessem Francezes, para viverem em igualdade, e abundancia, a cujo efeito tinha projectado de acordo com duzentas, e tantas pessoas, que tinha já chamado seo partido formar huma rebelião por meio da qual conseguiria os seos dezejos. ${ }^{43}$

Essas abordagens representam o que podemos considerar a última fase do movimento, após o aparecimento a 12 de agosto de 1798 de vários boletins espalhados pela cidade anunciando uma revolução para breve, contra "o pecimo jugo ruinavel da Europa", e pela qual "todos seremos iguaes". Soldados e artesãos, de modo pouco cuidadoso - como depois se mostrou, em função das delações - intensificaram o seu trabalho de arregimentação de mais pessoas para a causa, visando antecipar os planos de levante, sobretudo em função da prisão do soldado pardo Luís Gonzaga das Virgens, acusado de redigir aqueles papéis incendiários.

Os planos de levante teriam começado por ocasião do batizado de uma filha de Lucas Dantas, soldado e marceneiro mulato, no final de 1797, que contou com a presença do tenente Hermógenes Pantoja, irmão do padrinho, já repreendido pelo governador da 
capitania por promover círculos de reuniões e leituras sobre o sistema francês de governo. Lucas Dantas, a partir dessa ocasião, inseriu-se no movimento que, em suas palavras, se propunha a "fazer uma guerra civil entre nós para que não se distinga a cor branca, parda e preta". Não sabemos o número de pessoas mobilizadas para o levante e revolução, o contingente de partidários que João de Deus e outros chamavam simplesmente de "franceses".

E perguntando-lhe elle declarante [a Luis Pires, pardo, oficial de lavrante] pelos sinais distintivos de todos aquelles que se alistavão no partido da revolução, lhe respondeo que todos os que visse com brinquinho na orelha, barba crescida, até o meio do queixo, com hum buzio de Angola nas cadeas do relogio, este era Francez, e do partido da rebelião. ${ }^{44}$

Além de designar o revestimento das ideias e o do corpo dos partidários da conjuração, uma terceira referência a França/ franceses aparece diretamente associada às ideias do movimento:

[...] contra o Estado [os discursos se reduziam a] negar a subordinação e obediencia ao Rei e suas Leys, exaltando e louvando o systhema Francez e a sua legislação como tambem a sua forma do Governo, prifferindo-a ao deste Reino debaixo do principio de ser melhor a regencia de muitos do que de hum só. ${ }^{45}$

Tal remetimento às leis francesas também se fez presente no movimento conhecido como Inconfidência do Rio de Janeiro, de 1794. Francisco Antônio Lisboa, um dos acusados de traição à Coroa (inconfidência), teria dito que os fidalgos e os reis eram uns ladrões, e que isso só seria resolvido quando "chegassem ao Brasil as novas leis de
França", fazendo "os bens comuns e não admitindo fidalgos" . ${ }^{46}$ Outro acusado, o entalhador Francisco Antonio, teria dito que "as leis francesas eram boas pela igualdade que introduziam entre os homens, e que só quando os franceses chegassem se poriam as cousas direitas" ${ }^{\prime 7}$. E ainda João Antunes, marceneiro, "dizia aos seus escravos que, se a esta terra viessem os franceses, se lhes haviam de dar alguma cousa", e também que "o governo de muito era melhor porque sabiam mais várias cabeças do que uma só". 48

Além do dizer(-se) "francês" associa(n) do(-se) à revolução de 1789 e ao igualitarismo republicano, deve-se ter em conta outro elemento importante: $o$ alcance do que significava não dizer-se ou ser dito "português" em meio ao projeto imperial lusitano e sua formação ideológica dominante. Lembremos aqui o desejo do ministro da marinha e do ultramar, D. Rodrigo de Souza Coutinho, de ver a todo português, independentemente do território no qual tivesse nascido, julgando-se simplesmente português. Os colonos de fato identificavam-se como paulistas, mineiros, pernambucanos, baienses... mas todas essas eram formas específicas de ser português na América. ${ }^{49}$ Essa pequena especificidade parecia descabida no interior do reformismo ilustrado de Coutinho, ciente dos acontecimentos no norte da América que atropelaram a mais poderosa nação da época, a Inglaterra.

Desse modo, a referência a "francês" é opaca, possui espessura semântica, sendo campo de disputa entre formações discursivas $^{50}$ antagônicas: igualdade, república, liberdade, abundância $x$ caos, ruína, traição, violência, tirania, são termos que se inserem 
em dizeres distintos em razão das formas como são sustentados por diferentes sujeitos históricos. Seus sentidos provêm das formações discursivas que os disputam, metaforizam e parafraseiam. Por exemplo, ao narrar os acontecimentos da França revolucionária, a imprensa portuguesa, que circula sem entraves em Salvador, acusa a Convenção e a própria revolução de "tirania", carregando nas tintas ao falar do estado de violência em diversas cidades, projetando a imagem de ruas inteiras "juncadas de cadáveres", demonstrando também uma preocupação estratégica em qualificar como "exógeno à gente portuguesa o que se julgava nocivo nos acontecimentos franceses". ${ }^{51}$ Aliás, um tema constante dos Autos da Devassa da Conspiração dos Alfaiates - diante do qual julgamos válido manter acesa uma especial desconfiança - são as persistentes referências às intenções dos conjurados em matar os brancos da cidade, o que nos soa como prática ideológica conservadora de atemorização, mas também espelhamento no outro dos próprios desejos e interesses dominantes na eliminação física dos revolucionários.

$\mathrm{O}$ maior risco enunciado pelas autoridades metropolitanas era a difusão dos "clubes jacobinos franceses" e seus ideais pelas colônias. Segundo D. Rodrigo de Souza Coutinho, em carta de 1792 para os governadores do Brasil, "tinham sido esses abomináveis princípios a causar o fogo da revolta $\mathrm{e}$ insurreição que fizera os escravos erguerem-se contra seus senhores em S. Domingos" ${ }^{25}$ - processo este também acompanhado pela imprensa metropolitana portuguesa com grande ou até maior preocupação. Afinal, temos, nesse plano dos acontecimentos da colônia de São Domingos, futuro Haiti, uma primeira relação direta entre o republicanismo revolucionário francês, luta anticolonialista e abolição da escravatura - articulação ideológica esta que, originalmente, apontava para projetos "dessemelhantes e distintos", como escreve Robin Blackburn ${ }^{53}$ referindo-se ao entrelaçamento entre as contestações do domínio imperial por parte dos colonos e as da escravidão pelos próprios escravizados, que se aproveitariam do enfraquecimento dos aparatos de controle social.

Antes do início da revolução haitiana, o medo de uma rebelião escrava generalizada já estava disseminada entre as classes dominantes do império português. Depois, virou pesadelo. Em 1792, Manuel José de Novais de Almeida, médico residente em Lisboa e muito amigo de um dos acusados de inconfidência no Rio de Janeiro (1794), manifestou-se assim em carta ao amigo: “[...] estou com muito susto a respeito das Américas; as de França me trazem à lembrança o que pode um dia suceder às nossas; que permita Deus que eu nunca veja, porque sou amigo da humanidade", aconselhando em seguida ao amigo residente no Rio de Janeiro que alforriasse os seus escravos, passando a ser servido "com gente forra e livre", de modo a ter "menos inimigos". ${ }^{54}$ Conselho de amigo, mesmo. Diante desses temores, o alfaiate baiano João de Deus não fazia por menos, dizendo que os inimigos da liberdade não teriam nenhuma saída, pois nem mesmo trancados em casa estariam seguros: "[...] fia-Se Vossa mercê, e os mais em feixar as portas das suas cazas, dentro haverá quem as abra". Os escravizados, não referidos diretamente nos pasquins republicanos, saberiam como atuar na hora da revolução. 
Dentre os presos e condenados, o responsável pelo maior número de abordagens pessoais a escravizados era o alfaiate alforriado Manuel Faustino dos Santos Lira. A Ignacio Pires, de 17 anos, Lira teria dito que o levante "consistia em huma sublevação geral, pela qual havia de estabelecer hum novo Governo de igualdade, ficando extinto o cativeiro, e todos em liberdade", e que visava "o estabelecimento do Governo de igualdade e a liberdade para todos os escravos" ${ }^{55}$ Em junho, Lira teria anunciado a outro escravizado que o levante deveria ocorrer em breve:

[...] a fim de serem libertos todos os pretos e pardos cativos e viverem em huma igualdade tal, que não haveria distinção de ceres , e assim vivirião todos contentes; e devia elle declarante [Luís França Pires] ter huma espada, para nesse dia defender o partido do levante; e que a cauza da escravidão, em que vivião os pretos e pardos, nesta Cidade nascia da Igreja, de quem devião se queixar; e que o grande Bonaparte não tardaria aqui quatro mezes a defender com grande armada o partido da liberdade. ${ }^{56}$

Lira teria falado muitas vezes do "grande Napoleão Bonaparte" e também falava que "tinha muita gente rica e boa que entrava no levante" ${ }^{57}$ Lira foi preso no engenho pertencente ao proprietário de sua mãe, para onde tentou fugir; ele próprio morava na casa de sua madrinha, uma rica senhora ligada a uma das mais tradicionais famílias baianas, os Pires de Carvalho e Albuquerque. Esses e outros escravizados chamados por ele para o levante eram pertencentes à sua madrinha ou a José Pires de Carvalho e Albuquerque, detentor do posto (vitalício) de Secretário de Estado da capitania, todos eles foram entregues por seus senhores às autoridades.

\section{Desentendimentos, lutas ideológicas e assimetrias (serportuguês/ser francês)}

Não foi o republicanismo francês uma via de agenciamento para a luta anticolonial? Mas por que razão a libertação do jugo europeu, o fim da tirania monárquica, a abertura dos portos e a melhoria dos soldos imiscuíram-se com propostas de caráter social tão arrebatadoras e contrárias ao ordenamento social? Afinal, as referências à "escravidão" nos diferentes textos franceses que circulavam entre os revolucionários baianos referenciavam a negação da dita liberdade natural dos povos, ao direito natural dos homens, não remetendo senão metaforicamente à cena do trabalho compulsório e da propriedade de outro ser vivente. $\mathrm{O}$ igualitarismo republicano e revolucionário, que suprime ou dilui os aspectos sociais da (des)igualdade, ao ser trabalhado numa formação escravista colonial não produz somente antagonismo, mas também desentendimentos no tocante à reapropriação de um programa político.

Seria falso supor que os revolucionários baianos, ao menos uma parte importante deles, ignorassem os acontecimentos e as adversidades da Revolução Francesa em seu desenrolar. Mas falamos de história, não de transferência de dados e univocidade das experiências, o que deve implicar na consideração do atravessamento de processos inconscientes, dentre os quais a própria luta de classes que é, de modo dinâmico e contraditório, o que engendra as classes sociais. István Jancsó, por exemplo, nos conta do entusiasmo e da imprudência, sobretudo por parte de alguns jovens baianos, com a pre- 
sença de franceses na cidade em 1796-1797. Causou estranheza a um desses franceses "que nunca perguntassem a respeito de suas opiniões sobre o que ocorria na França, bastando-lhes, como penhor de sua simpatia, saber 'que eram franceses' os interlocutores, vindos da 'Pátria da Filosofia'". 58

Toda transferência falha, o que não significa dizer que toda falha seja sofrida e deva ser considerada apenas equívoco, e não uma possível esquiva. Jancsó diz que a busca de participação na sociedade política por parte de homens egressos da condição escrava (e do povo mecânico, acrescentamos) não poderia ser assimilada pelas classes dominantes. ${ }^{59}$ Julgamos importante destacar que não foram estes os únicos problemas de assimilação na efetivação do pacto revolucionário que se buscou produzir, pacto este que seria o instituidor de uma nova nação, muito distante esta da que foi desenhada com a independência de 1822, como também esteve distante das ideologias de nação anteriores à Revolução Francesa, fundadas em direitos e trajetórias ancestrais de sangue, voltados sempre a retomadas de um passado perdido, e não para rupturas revolucionárias. ${ }^{60}$

O confronto delineado em 1798 na Bahia colocava frente a frente a monarquia e uma comunidade que afirmava ter configuração específica; o povo bahinense instituidor potencial de um novo Estado que viria a ser nacional mediante um pacto de cidadãos [...]. O inimigo do povo não tinha uma configuração nacional, a opressão não era percebida como a de uma nação estrangeira. Não era assim que a dominação era reconhecida, pois a privação da liberdade do povo bahinense não advinha da sujeição à nação portuguesa, mas ao trono. ${ }^{61}$

Uma observação: a instituição de tal pacto é inseparável da instituição destes próprios cidadãos, da sua subjetivação, na conjugação de um campo de experiências e horizonte de expectativas que rompem "a configuração sensível na qual se definem as parcelas e as partes ou sua ausência a partir de um pressuposto que por definição não tem cabimento ali: a de uma parcela dos sem-parcela". ${ }^{62}$

Enquanto as práticas discursivas identitárias que chamamos de "artes de lembrar e artes de fazer esquecer" podem ser compreendidas sob um mesmo tecido ideológico de evidências e compromissos, variando mais as posições de sujeito (colonos ou colonizadores) do que a formação discursiva (a qual podemos chamar de o "ser português"), no caso da identificação com os franceses, equívoca, opaca, desviante, ela provoca a implosão dos enquadramentos ideológicos prévios, configurando de fato um acontecimento histórico, discursivo e enunciativo. ${ }^{63}$ É esse outro "problema de assimilação", esse desentendimento relativo ao "ser francês" na formação social escravista colonial, que representava um entrave muito maior à (ou do que a) incorporação de novos sujeitos à sociedade política local de Salvador.

Com isso dizemos que o horizonte de expectativas traçado pelo igualitarismo republicano "fora de lugar" na colônia escravista é bem mais subversivo que a reconfiguração do campo de experiências mediante uma aceitação e incorporação de egressos das camadas plebeias - afinal, em tempos não tão remotos, os mestiços do Brasil já haviam sido significativamente beneficiados nos quadros da sociedade escravista colonial, ${ }^{64}$ sendo um dos dizeres populares de maior alcance e circulação na América 
Portuguesa do século XVII aquele que afirma ser a colônia "paraíso dos mulatos, purgatório dos brancos e inferno dos negros". Queremos com isso dizer também que aquilo que os sujeitos dizem, ou que finalmente conseguem dizer e fazer com que seja ouvido/lido, pode importar tanto quanto aquilo que deles se diz, e que os prende sempre às arapucas ideológicas que somente atualizam uma derrota, como a dos colonizados em relação aos colonizadores e colonos.

As lutas ideológicas jamais se colocam num jogo dualista entre pontos de vista, concepções de mundo e sensibilidades que, em última instância, se ofereceriam enquanto oposições conceituais bem comportadas e simuladoras de alternância. $\mathrm{O}$ verdadeiro antagonismo hoje, por exemplo, não é entre mercado e Estado, financeirização da economia e aumento da produtividade, tucanos e petistas, fundamentalismo e democracia... mas sim entre esses "antagonismos oficiais" e aquilo que eles "foracluem", de modo a podermos mobilizar aqui a fórmula lacaniana do $1+1=3$, pela qual o resultado inesperado se dá em razão das consequências de um "resto indizível" (produtor de efeitos) no interior desta conta supostamente binária, que em verdade deve ser representada como " $1+1+a$ ". ${ }^{65}$ Normalmente nos deparamos com a existência de um campo ideológico que impõe uma visibilidade e uma organização das contradições a seu próprio modo, de forma a que uma posição dissidente qualquer, a despeito de sua singularidade, possa quase sempre ser enquadrada no esquema previamente estabelecido. É ainda como se toda ideologia dominante trouxesse como sua contraparte outra ideologia, uma contraidentificação que não faz mais do que dar vitalidade a um mesmo campo de (o)posições estabelecidas, reais ou imaginárias.

Michel Pêcheux, abordando esses confrontos entre identificação e contraidentificação no campo das discursividades, falará da tendência à simetrização e dicotomização do campo político. ${ }^{66}$ Como pudemos bem acompanhar e como tão bem nos mostram István Jancsó e João Paulo Pimenta, a posição do povo bahinense republicano, naquilo que se identifica com os franceses, não se presta a nenhuma simetrização e dicotomização em relação ao ser português, rompendo com a concepção hegemônica de nação, aquela da sujeição a uma determinada Casa Real/Estado, e instituindo outra pela qual a parcela dos sem-parcela, a "miserável gente" plebeia, os desclassificados, busca fazer ver o que não cabia ser visto, fazer ouvir um discurso onde só tinha lugar o barulho, fazer ouvir como discurso o que só era ouvido como barulho, desfazendo assim as divisões sensíveis da ordem policial. ${ }^{67}$

Os franceses baianos deslocaram-se do campo ideológico vigente, trabalhando o impossível de sua integração na sociedade política colonial, a impossibilidade de serem realmente portugueses. Mas trabalharam também, e, sobretudo, o impossível do igualitarismo republicano numa ordem escravista, a impossibilidade de serem realmente franceses. As revoluções, afinal são sempre isso: uma série de atos, uma práxis, um trabalho sobre o campo - histórico - do impossível. 


\section{Abstract}

In this article, we discuss the political and discursive displacement that, amidst the Conjuração Baiana, caused the word nation to stop referring to subjection to a given sovereignty and to start meaning something other than a change of masters. Thus, it pointed out to the construction of a political project that did not fit in the dominant ideological field, one that imposes a visibility, an alternation and an organization of the contradictions in its own way. If it was not about the antagonism between "being Portuguese" and "being French" in Bahia at the end of the $18^{\text {th }}$ century, if the true antagonism was between republic and monarchy, then it is necessary to underline both the difficulty of assimilation of the mechanical and non-white people to local political society and the misunderstanding and the equivocity of "being French" inside colonial slavery formation. We conclude that what subjects say can matter as much as what is said of them: the revolutionaries from Bahia did not have to pay only for their social origin, but also and fundamentally for what they said and made others listen.

Keywords: Conjuração Baiana. Discourse. Ideology. Misunderstanding. Nation.

\section{Resumen}

En este artículo discutimos el dislocamiento político y discusivo que, en medio a la Conjuração Baiana de 1798, hace con que nación deje de referirse a sujeción a una determinada soberanía y pase a significar otra cosa que no un cambio de señores, apuntando así para la construcción de un proyecto político que no cabe en el campo ideológico dominante, aquello que impone una visibilidad, una alternancia y una organización de las contradicciones a su proprio modo. Si no se trataba de antagonismo entre "ser portugués" y "ser francés" en Bahia al fines de siglo XVIII, si el verdadero antagonismo se daba entre república y monarquía, es el caso de subrayar tanto la dificultad de asimilación del pueblo mecánico y no blanco a la sociedad política local, como el desentendimiento y el equívoco de ese "ser francés" en el interior de la formación esclavista colonial. Consideramos, en fin, que aquello que los sujetos dicen puede importar tanto cuanto aquello que de ellos se dice: los revolucionarios baianos no tuvieron de pagar apenas por su origen social, mas también y fundamentalmente por lo dijeron e hicieron oír.

Palabras-clave: Conjuração Baiana. Desentendimiento. Discurso. Ideología. Nación.

\section{Notas}

1 GRAMSCI, Antonio. Cadernos do Cárcere. (v. III, Maquiavel - notas sobre o Estado e a política). 2. ed. Trad. de Luís S. Henriques, Marco A. Nogueira e Carlos N. Coutinho. Rio de Janeiro: Civilização Brasileira, 2002 [1929-35], p. 20.

2 JANCSÓ, István. Na Bahia, contra o império: história do ensaio de sedição de 1798. São Paulo: Hucitec; Salvador: EDUFBA, 1996, p. 105.

3 Testemunho de Francisco Xavier de Almeida, branco, procurador de causas, 57 anos, nos Autos da Devassa da Conspiração dos Alfaiates. 2 volumes. Salvador: Secretaria da Cultura e Turismo/Arquivo Público do Estado, 1998, p. 318. 
4 JANCSÓ, István; PIMENTA, João Paulo G. Peças de um mosaico (ou apontamentos para o estudo da emergência da identidade nacional brasileira). In: MOTA, Carlos Guilherme (Org.). Viagem incompleta. A experiência brasileira (1500-2000). Formação: histórias. São Paulo: Editora Senac, 2000, p. 127-175, p. 143.

5 ALENCASTRO, Luiz Felipe de. O trato dos viventes: formação do Brasil no Atlântico Sul. São Paulo: Companhia das Letras, 2000.

6 Ibid.

7 FIGUEIREDO, Luciano Raposo de Almeida. “Narrativas das rebeliões. Linguagem política e idéias radicais na América Portuguesa moderna". Revista USP, São Paulo, n. 57, p. 6-27, mar./ maio 2003.

8 Citada por Luciano Raposo de Almeida Figueiredo, op. cit., p. 9.

9 Ibid., p. 13.

10 Citado por Luciano Raposo de Almeida Figueiredo, op. cit., p. 10.

11 Citado por Robin Blackburn, A queda do escravismo colonial: 1776-1848. Trad. de Maria Beatriz Medina. Rio de Janeiro: Record, 2002 [1988], p. 26.

12 GORENDER, Jacob. O escravismo colonial. 4. ed. São Paulo: Fundação Perseu Abramo, 2010 [1985], p. 94.

13 ALENCASTRO, Luiz Felipe de. Op. cit., p. 87.

14 ARAÚJO, Ubiratan Castro de. A política dos homens de cor no tempo da independência. In: Clio - Revista de Pesquisa Histórica, Recife, n. 19, p. 7-27, 2001, p. 10-11.

15 ALENCASTRO, Luiz Felipe de. Op. cit., p. 168-180.

16 Citado por Stuart Schwartz, Gente da terra braziliense da nasção. Pensando o Brasil: a construção de um povo. In: Mota (Org.). Viagem incompleta. A experiência brasileira (1500-2000). Formação: histórias. São Paulo: Editora Senac, 2000, p. 103-125, p. 110 .

17 Citado por Stuart Schwartz, op. cit., p. 109.

18 Como explica Tarquínio Oliveira em nota dos Autos de Devassa da Inconfidência Mineira. Brasília: Câmara dos Deputados, 1977, v. 9, p. 65.

19 JANCSÓ, István; PIMENTA, João PauloG. Op. cit., p. 136.

20 Argumento desenvolvido na tese - Rodrigo Oliveira Fonseca, A interdição discursiva: o caso da Conjuração Baiana e outros limites à participação popular na história política do Brasil. Tese de doutorado (PPG Letras UFRGS), 2012 - e que é tributário da leitura de Jacob Gorender, op. cit., e de João Luís Fragoso, Homens de grossa aventura: acumulação e hierarquia na praça mercantil do Rio de Janeiro (1790-1830). 2. ed. rev. Rio de Janeiro: Civilização Brasileira, 1998.
21 JANCSÓ, István; PIMENTA, João Paulo G. Op. cit., p. 130

22 VILLALTA, Luiz Carlos, 1789-1808: o império luso-brasileiro e os Brasis. São Paulo: Companhia das Letras, 2000, p. 15.

23 Citado por Luiz Carlos Villalta, op. cit., p. 31.

24 MARIANI, Bethania. Colonização linguística: línguas, política e religião no Brasil (séculos XVI a XVIII) e nos Estados Unidos da América (século XVIII). Campinas: Pontes, 2004, p. 106-112.

25 Idem, p. 107-112.

26 Carboni; Mário Maestri, A linguagem escravizada: língua, história, poder e luta de classes. 2. ed. rev. e amp. São Paulo: Expressão Popular, 2003, p. 68.

27 Citado por Luiz Felipe de Alencastro, op. cit.

28 FALCON, Francisco J. Calazans. O povo brasileiro: ensaio historiográfico. Revista USP, São Paulo, n. 46, p. 30-41, jun./ago. 2000, p. 34.

29 MARIANI, Bethania. Op. cit., p. 112-114.

30 CARBONI, Florence; MAESTRI, Mário op. cit., p. 18-22.

31 Citado por Bethania Mariani, op. cit.

32 JANCSÓ, István; PIMENTA, João Paulo G. op. cit., p. 145.

33 Raphael Bluteau, Vocabulario portuguez E latino, 1728,p.658. Disponívelem:http:/ www.brasiliana. usp.br/en/dicionario/1na\% $\% 3 \%$ A7\% C3\% A3o. Acesso em: 7 dez. 2012.

34 PINTO, Luiz Maria da Silva. Diccionario da Lingua Brasileira, 1832. Disponível em: http:// www.brasiliana.usp.br/en/dicionario/3/ na\%C3\%A7\%C3\%A3o. Acesso em: 07 dez. 2012.

35 Citado por Luciano Raposo de Almeida Figueiredo, op. cit.

36 Citado por Reinhart Koselleck, Crítica e crise: uma contribuição à patogênese do mudo burguês. Rio de Janeiro: EdUERJ; Contraponto, 1999 [1973], p. 119.

37 MATTOSO, Katia M. de Queirós. Presença francesa no movimento democrático baiano de 1798 . Bahia: Itapuã, 1969. TAVARES, Luís Henrique Dias, História da sedição intentada na Bahia em 1798: a conspiração dos alfaiates. São Paulo: Pioneira; Brasília, INL, 1975. JANCSÓ, István; MOREL, Marco. Novas perspectivas sobre a presença francesa na Bahia em torno de 1798. In: Revista Topoi, Rio de Janeiro, v. 08, n. 14, jan./jun. 2007, p. 206-232.

38 KOSELLECK, Reinhart. Futuro passado: contribuição à semântica dos tempos históricos. Rio de Janeiro: Contraponto, 2006 [1979].

39 RANCIÈRE, Jacques, $O$ desentendimento: política e filosofia. Trad. de Ângela Leite Lopes. São Paulo: Editora 34, 1996, p. 47.

40 FONSECA, Rodrigo Oliveira. op. cit. 
${ }^{41}$ GUILHAUMOU, Jacques; MALDIDIER, Denise. Da enunciação ao acontecimento discursivo em análise do discurso. Trad. de Freda Indursky. In: Guimarães (Org.). História e sentido na linguagem. Campinas, SP: Pontes, 1989, p. 66.

42 BADIOU, Alain. Para uma nova teoria do sujeito: conferências brasileiras. Trad. de Emerson Xavier da Silva e Gilda Sodré. Rio de Janeiro: Relume-Dumará, 1994, p. 17.

43 Depoimento de Joaquim José da Veiga, pardo, oficial de ferrador. Autos da Devassa..., p. 284.

44 Depoimento de José de Freitas Sacoto, pardo livre, negociante de ouro e prata e cirurgião, Autos da Devassa..., p. 753.

45 Depoimento de Manuel de Santa Anna, soldado pardo, 30 anos, Autos da Devassa..., p. 878.

46 Extraído dos Autos da Devassa do Rio de Janeiro, citado por L. C. Villalta, op. cit., p. 88.

47

50 PÊCHEUX, Michel. Semântica e discurso: uma crítica à afirmação do óbvio. Trad. de Eni Orlandi [et al.]. 3. ed. Campinas, SP: Editora da Unicamp, 1997 [1975].

51 VILLALTA, Luiz Carlos. op. cit., p. 25.

52 Citado por Luiz Carlos Villalta, op. cit., p. 28.

53 BLACKBURN, Robin. A queda do escravismo colonial: 1776-1848. Trad. de Maria Beatriz Medina. Rio de Janeiro: Record, 2002 [1988], p. 15.

54 Luiz Carlos Villalta, op. cit., p. 74.

55 Autos da devassa da conspiração dos alfaiates, op. cit., p. 794 e 797.

56 Depoimento de Luís França Pires, pardo, escravizado, alfaiate, 32 anos, Autos da devassa da conspiração dos alfaiates, op. cit., p. 386.

57 Idem, p. 389.

58 JANCSÓ, István. Contrabando e ideias. In: LEMOS, Domingues; YGLESIAS (Org.). Animai-vos, Povo Bahinense! A conspiração dos alfaiates. Salvador: Omar G. Editora, 1999, p. 60-61.

59 JANCSÓ, István. Na Bahia, contra o império..., p. 70

60 Idem, p. 174.

61 JANCSÓ, István; PIMENTA, João Paulo G. Op. cit., p. 147.

62 RANCIÈRE, Jacques. Op. cit., p. 42-43.

63 INDURSKY, Freda. Lula lá: estrutura e acontecimento.Organon(UFRGS), PortoAlegre, v. 17, n. 35, 2003, p. 101-121, p. 107; e Id., Unicidade, Desdobramento, Fragmentação: trajetória da noção de sujeito em análise do discurso. In: MITTMANN,
Grigoletto; CAZARIN (Org.). Práticas discursivas e identitárias: sujeito e língua. Porto Alegre: Nova Prova, 2008, p. 9-33, p. 22-30.

64 ALENCASTRO, Luiz Felipe de. op. cit., com destaque para a seção $A$ invenção do mulato.

65 ZIZEK, Slavoj. Em defesa das causas perdidas. Trad. de Maria Beatriz de Medina. São Paulo: Boitempo, 2011, p. 382.

66 PÊCHEUX, Michel. op. cit., p. 206.

67 RANCIÈRE, Jacques. op. cit., p. 42-43. 